\title{
Reproduction and Genetic Stability of Long-Term Proliferative Embryogenic Cell Lines of Larix Sibirica
}

\section{In Vitro}

\author{
Iraida $\mathrm{NT}^{1 *}$, Maria $\mathrm{EP}^{1}$, Alyona $\mathrm{SI}^{1}$, Alla SS1 and Inga $\mathrm{AL}^{2}$ \\ ${ }^{1}$ VN Sukachev Institute of Forest SB RAS, Federal Research Center Krasnoyarsk Science Center SB RAS, Russia \\ ${ }^{2}$ Siberian Federal University, Russia
}

Submission: February 22, 2017; Published: May 03, 2017

*Corresponding author: Iraida NT, VN Sukachev Institute of Forest SB RAS, Federal Research Center Krasnoyarsk Science Center SB RAS, 50/28 Akademgorogok, Krasnoyarsk, 660036, Russia, Email: culture@ksc.krasn.ru

\begin{abstract}
The study of quality, reproduction and somaclonal changes of long-term proliferative Embryogenic cultures of Larix sibirica in vitro was conducted. Produced cell lines of Larix sibirica were characterized by high Embryogenic productivity. Multiplication of somatic embryos was activated through the cleavage budding and disintegrating suspensor cells. Cultivated Embryogenic cultures did not change the ploidy for seven years. According to microsatellite analysis proliferating cell lines of Siberian larch was characterized by weak allelic variability, and four-year cloned seedlings were genetically stabled.
\end{abstract}

Keywords: Larix sibirica; Somatic embryogenesis; Somaclonal variation; Microsatellite analysis; Embryogenic productivity.

\section{Introduction}

Siberian larches (Larix sibirica Ledeb.) in Siberia have poor seed crops, low seed quality, and even do not produce seeds in bad-seed years and their generative organs are often damaged by forest pests. The greatest reduction of larch productivity is caused by larch bud midge (Dasineura rozhkovi Mam. et Nik.) who damages larch generative and vegetative buds and, as a result, they become galls. However, some larches $0.5 \%$ of all trees in any given larch stand) are resistant to the midge.

In order to solve the problem of plant regeneration in larch species, researchers elaborate the programs based on biotechnologies for microclonal propagation, such as somatic embryogenesis [1-4]. However, the study of the genetic stability of Embryogenic cell cultures of Larix marschlinsii [5], Larix decidua [6], Pinus pinaster [7], P. sylvestris [8] and others showed increased frequency of mutations and genetic instability, which increased with prolonged culturing of Embryogenic callus. However, a number of authors indicate that in the process of somatic embryogenesis in some species Picea abies, P. glauca, P. mariana x P. glauca [9-13] and Pinus pinaster [14] somaclonal variation were not detected and regenerated was the same as the original explants.

In this paper we present the results of a study of the quality and reproduction of long-term proliferative Embryogenic cultures (Embryogenic productivity) and somaclonal changes in the cell lines of Larix sibirica.

\section{Materials and Methods}

Seven Embryogenic cell lines of Siberian larch (Larix sibirica Ledeb.) were chosen from the donor-tree № 4A (Cl2, Cl4, Cl5 initiated in 2009, Cl6 initiated in 2011) and from the donor-tree № 10 (Cl101 and Cl102 initiated in2011). Trees grow in the arboretum of the V.N. Sukachev Institute of forest SB RAS, (Krasnoyarsk). Isolated zygotic embryos at the stages of globular embryo, cotyledon initiation and development were used as the material for induction of somatic embryogenesis. After sterilization, under sterile conditions of laminar hood, embryos were removed from mega gametophytes and placed on the culture medium.

Callus induction. The following mineral bases of the basal media were used for callus induction in larch AI media (patent №2456344 http://www.freepatent.ru/patents/2456344). 2.4-Dichlorophenoxyaceticacid (2.4-D) (2mgl-1) and benzyl adenine (BA) (1mgl-1) were used as growth regulators. The medium was treated with agar at a concentration of $7 \mathrm{gl}-1$; medium $\mathrm{pH}$ was adjusted to 5.8 before autoclaving that was carried out at $121^{\circ} \mathrm{C}$ for $20 \mathrm{~min}$. After autoclaving, L-glutamine and ascorbic acid was added to the chilled nutrient medium. Five 
embryos per Petri dish were cultured in $20 \mathrm{ml}$ of the induction medium in darkness at $25^{\circ} \mathrm{C} \pm 1^{\circ} \mathrm{C}$.

\section{Proliferation of embryonic mass}

The above cited basal media containing 2.4-D (2mgl$1)$, BA $(0.5 \mathrm{mgl}-1)$, and sucrose $(20 \mathrm{gl}-1)$ were used for callus proliferation and formation of Embryogenic mass. Culturing regime was the same as that one during callus induction. Callus was transferred to fresh nutrient medium every two weeks. Maturation and germination of somatic embryos were described by us earlier [15].

\section{Cytological and statistical analysis}

Squash preparations were used to perform cytological analysis. In order to obtain squash preparations, the explants were placed on a slide plate and kept in the staining agent (safranin with methylene blue) for 1-2min. Glycerol was added, and the preparation was then cover slipped. The Embryogenic productivity of cell lines (Embryogenic potential) was estimated (number of embryos per $1 \mathrm{~g}$ fresh mass of callus). Cells and embryonic structures were measured by means of an eyepiece micrometer and the obtained values were then converted in $\mu \mathrm{m}$. The micro samples were examined under a LOMO MICMED-6 microscope.

\section{Microsatellite analysis}

Table 1: Microsatellite loci were selected for genotyping larch

\begin{tabular}{|c|c|c|c|}
\hline Loci & Мотив & $\begin{array}{c}\text { Size of } \\
\text { Fragment }\end{array}$ & Literature \\
\hline bcLK056 & $(\mathrm{AG}) 20$ & $174-200$ & \multirow{9}{*}{$\begin{array}{l}\text { Krutovsky } \\
\text { et al. [17] }\end{array}$} \\
\hline bcLK066 & (TG)12 & $155-172$ & \\
\hline bcLK224 & (AG)17 & $152-168$ & \\
\hline bcLK225 & $(\mathrm{GA}) 20$ & $180-213$ & \\
\hline bcLK232 & (AG)19 & $142-178$ & \\
\hline bcLK260 & (TG)14(AG)9 & $115-126$ & \\
\hline bcLK235 & (TC)9(AC)2AG(AC)14 & $177-220$ & \\
\hline UBCLXtet_1-22 & (TATC)9(TA)12 & $175-250$ & \\
\hline UAKLly6 & (GT)17 & $214-264$ & \\
\hline
\end{tabular}

For genotyping of microsatellite loci DNA was used, isolated from the needles of the parent trees № 4A and №10 resistant to the larch Bud Midge and EMS six Cells obtained from these trees (Cl2, Cl4 Cl5, Cl.6, Cl101, Cl102 and one no Embryogenic line). DNA was isolated according to standard methods using BECOMING [16]. The isolated DNA was used for PCR with 9 pairs of oligonucleotides-primers previously developed for microsatellite sequences of different species of larch [17]. The amplification products were separated by electrophoresis in $6 \%$ polyacrylamide gel in a cell for vertical electrophoresis, using a Tris-EDTA-borate electrode buffer. Visualized with a system gel-documentation. The molecular weight of the fragments was determined by comparing with standard marker in Photo-Capt. As a marker of standard lengths used plasmid pBR322 DNA treated with HpaII restrictive. In (Table 1). Micro satellite loci were selected for genotyping larch.

\section{Statistical analysis}

Data were statistically processed as described elsewhere using Microsoft Excel. One-way and two-way analysis of variance was performed to assess the reliability of the results [18].

Results

\section{Reproduction somatic embryos}

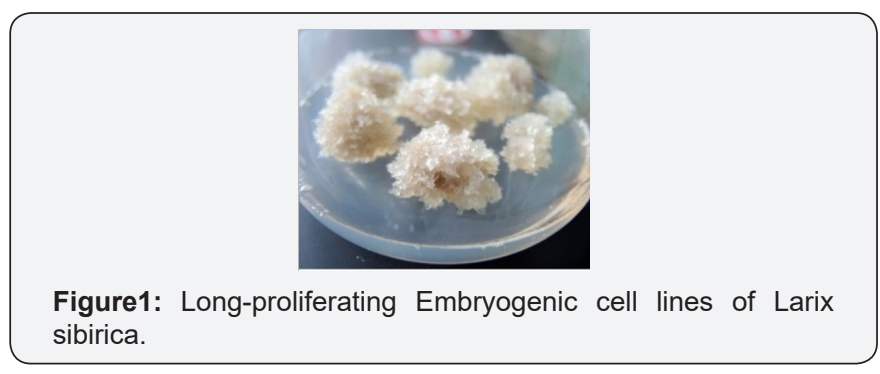

We study 7Cls from 23 Embryogenic cultures. The Cls were represented by white and friable EC, which actively formed ESM (Figure 1). Histological examination showed that ESM of larch consisted from globular embryos and embryonic tubes. The number of globular somatic embryos in different $\mathrm{Cls}$ ranged from 2180 (CL2) to 8750 (Cl101) in 1gr. ESM. Size of globules of somatic embryos at different Cls varied from 90 (Cl5) to $282 \mu \mathrm{m}$ (Cl6), suspensor from 592 to 2969 microns.

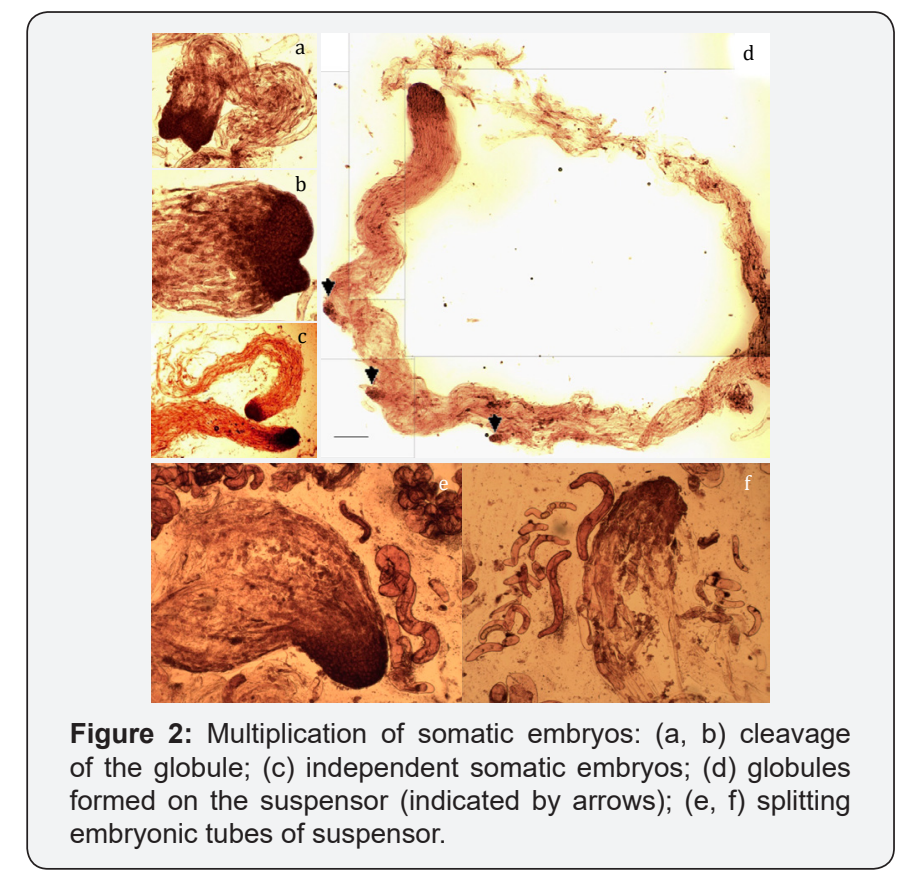

Multiplication of somatic embryos has gone through the cleavage. Cleavage occurred regardless of the size of the globules. It can occur in small (size is $50 \mu \mathrm{m}$ ) as well as in large globules (size is $282 \mu \mathrm{m}$ ).In large globules, there was an active initiation of meristematic foci and division of globules into separate identical parts. All of the parts increased their size simultaneously and attained the form of a head of somatic embryos. Then the bottom 
cells of the embryonic head formed the embryonic tubes, which in turn formed suspensor (Figure 2a \& 2b).

The rate of cleavage did not weaken during the long-term culturing and each of derived embryos separated from each other. As a result of this process independent somatic embryos have a risen (Figure 2c). In addition, the formation of somatic embryos was observed as well in the suspensor cells as a consequence of lateral suspensor protrusion or budding (Figure 2d). Moreover, actively multiplication of somatic embryos occurred directly from the suspensor cells. During this process the embryonic tubes, which composed the suspensor, have split. In elongated cells (embryonic tubes) an asymmetrical division was observed and the formation of globules and suspensor of somatic embryo occurred (Figure 2e \& 2f). This picture resembled the first stages of somatic embryogenesis initiation. Thus, multiplication of globular somatic embryos actively passed as a result of cleavage of embryos, suspensor budding and embryonic tubes of suspensor proliferation.

\section{Microsatellite analysis}

Table 2: Microsatellite loci and genotypes of donor trees (4A and 10) and Cl2, Cl4, Cl5, Cl6, NE and Cl101 and 102.

\begin{tabular}{|c|c|c|c|c|c|c|c|c|c|}
\hline Loci & $\mathbf{4 A}$ & $\mathbf{C l 2}$ & $\mathbf{C l 4}$ & $\mathbf{C l 5}$ & $\mathbf{C l 6}$ & $\mathbf{N E C l}$ & $\mathbf{1 0}$ & $\mathbf{C l 1 0 1}$ & $\mathbf{C l 1 0 2}$ \\
\hline bcLK056 & $145 / 145$ & $175 / 145$ & $173 / 145$ & $169 / 169$ & $145 / 145$ & $165 / 165$ & $165 / 165$ & $165 / 165$ & $165 / 165$ \\
\hline bcLK066 & $151 / 151$ & $151 / 151$ & $151 / 151$ & $151 / 141$ & $151 / 151$ & $151 / 151$ & $151 / 151$ & $151 / 151$ & $151 / 151$ \\
\hline bcLK224 & $130 / 130$ & $130 / 130$ & $130 / 130$ & $130 / 130$ & $130 / 130$ & $130 / 130$ & $130 / 130$ & $130 / 130$ & $130 / 130$ \\
\hline bcLK225 & $205 / 205$ & $168 / 168$ & $205 / 205$ & $205 / 205$ & $183 / 183$ & $168 / 168$ & $205 / 205$ & $205 / 168$ & $168 / 168$ \\
\hline bcLK232 & $134 / 134$ & $134 / 134$ & $134 / 134$ & $134 / 134$ & $134 / 134$ & $134 / 134$ & $134 / 134$ & $134 / 134$ & $134 / 134$ \\
\hline bcLK235 & $216 / 208$ & $216 / 208$ & $216 / 198$ & $208 / 198$ & $208 / 208$ & $216 / 208$ & $226 / 198$ & $198 / 192$ & $208 / 208$ \\
\hline bcLK260 & $102 / 102$ & $102 / 102$ & $102 / 102$ & $102 / 102$ & $102 / 102$ & $102 / 102$ & $102 / 102$ & $102 / 102$ & $102 / 102$ \\
\hline UBCLXtet_1-22 & $180 / 180$ & $180 / 180$ & $180 / 180$ & $180 / 180$ & $180 / 180$ & $180 / 180$ & $180 / 180$ & $180 / 180$ & $180 / 178$ \\
\hline UAKLly6 & $240 / 234$ & $234 / 234$ & $240 / 238$ & $240 / 240$ & $240 / 240$ & - & $254 / 254$ & $250 / 234$ & $234 / 234$ \\
\hline
\end{tabular}

The result of the study showed that only two loci bcLK235 and UAKLly6 were heterozygous in the parent tree No. 4A, and one locus bcLK235 in the parent tree No. 10 (Table 2). In locus bcLK235 only $\mathrm{Cl} 2$ was identical to the parent tree. In this locus $\mathrm{Cl} 4$ had one allele corresponding parent tree and the second allele is not. In all four cell lines $(\mathrm{Cl} 2, \mathrm{Cl} 4, \mathrm{Cl} 5, \mathrm{Cl} 6)$ we found only one allele that corresponds to the parent tree No. 4A in locus UAKLly6. Wherein $\mathrm{Cl} 2, \mathrm{Cl} 5$ and $\mathrm{Cl} 6$ were homozygous, whereas $\mathrm{Cl} 4$ was heterozygous and has the single allele, which was identical to the maternal genotype $(240 / 238)$. In loci bcLK066, bcLK224, bcLK232, bcLK260, UBCLXtet_1-22 in all cell lines showed complete identity with the parent tree No. 4A. In loci bcLK066, bcLK224, bcLK232, bcLK260, UBCLXtet_1-22 in all cell lines showed complete identity with the parent tree No. 4A, Cl5 was the only exception, which had in locus bcLK066 genotype $151 / 141$ while the genotype of the mother tree at this locus $151 / 151$.

Cl6 deserves special attention of all tested cell lines of the parent tree No. 4A, which at nine studied loci seven loci were completely identical to the genotype of the parent tree. At locus bcLK225 in this cell line was identified genotype different from the genotype of the parent tree. The Cl6 had a homozygous genotype in locus UAKLly6 and was similar to the donor tree in one of the alleles. At the Cl101, Cl102 derived from tree No. 10 observed changes in the three loci (bcLK225, bcLK235, UAKLly6). In Cl101, two alleles different from the maternal tree were identified only at locus UAKLly6, and similarity with one allele was found at loci bcLK225 and bcLK325 (Table 2). In CL102, in all loci described above, the genotypes and allelic diversity did not correspond to the maternal tree.

In general, nuclear microsatellite loci genotyping of cell lines showed that the majority of alleles at identified loci corresponded to the maternal donor tree. The changed alleles of CL, observed at individual loci, probably indicated the manifestation of the paternal genotype, which inevitably appeared during free pollination.

\section{Maturation and germination of somatic embryos}

A high degree of somaclonal variability of the phenotype was observed during the process of maturation of somatic embryos of Larix sibirica on AI nutrient medium with ABA. At the same time, mainly normal embryos were formed by morphogenesis in highly productive cell lines (e.g., $\mathrm{Cl}_{4}$ ). In $\mathrm{Cls}$ with lower Embryogenic productivity, the number of abnormal somatic embryos was much higher. Especially these abnormalities were characteristic for the basal domain. Phenotypic ally abnormal embryos are probably incapable of forming regenerates.

\section{Conclusion}

Somatic embryogenesis of Larix sibirica has the potential to produce plants through in vitro propagation. Embryogenic potential in long-proliferating cell lines of Siberian larch remained at the same level as in the young cultures (under 1 year). However, long-proliferating (seven years and longer) Larix sibirica cell lines remained highly Embryogenic throughout the proliferation period. In our studies, the ploidy of Embryogenic cultures of Larix sibirica did not change during the 2-7 years of culturing. The number of chromosomes was diploid. 
Microsatellite analysis of proliferating Embryogenic cultures of Siberian larch that we performed showed weak allelic variation of cell lines and full compliance of cultures with the donor tree.

We believe that embryo anomalies during maturation was eliminated at the final stage of embryogenesis and that viable plantlets developed from embryos which had no morphogenetic an able to develop in the fast-growing seedlings. These 4 -year seedlings of Larix sibirica successfully grow in the greenhouse of the Institute of Forest Experimental station Pogorelsky Bor. These seedlings are genetically stable and can be recommended as planting material for the forest plantation of larch in Siberia (Figure 3).

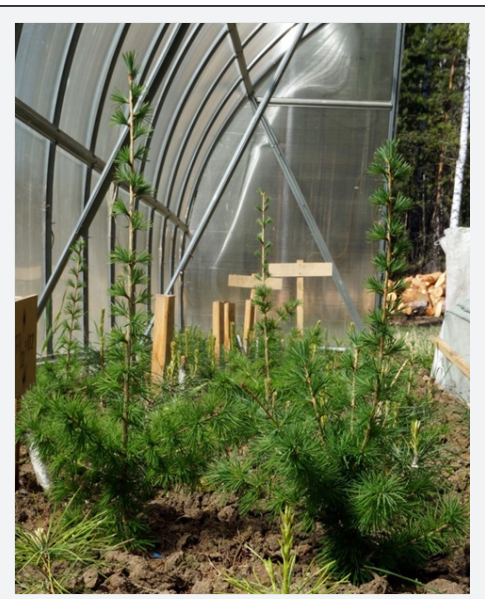

Figure 3: Somatic seedlings of Larix sibirica in the Pogorelsky Bor research forest.

The reported study was funded by Russian Foundation for Basic Research project №15-04-01427 and Russian Foundation for Basic Research, Government of Krasnoyarsk Territory, Krasnoyarsk Region Science and Technology Support Fund to the research project №16-44-240509.

\section{References}

1. Lelu MA, Bastien C, Ward C, Klimaszewska K, Charest P, et al. (1994a) An improved method for somatic plantlet production in hybrid larch (Larix x leptoeuropaea): Part 1 Somatic embryo maturation. Plant Cell Tissue Organ Cult 36(1): 107-115

2. Lelu MA, Klimaszewska K, Charest P (1994b) Somatic embryogenesis from immature and mature zygotic embryos and from cotyledons and needles of somatic plantlets of Larix. Can J For Res 24(1): 100-106.

3. Lelu Walter MA, Pâques LE (2009) Simplified and improved somatic embryogenesis of hybrid larches (Larix $\times$ eurolepis and Larix $\times$ marschlinsii) Perspectives for breeding. Ann For Sci 66: 100 -104.

4. Park YS, Bonga J, McCartney A, Adams G (2014) Integration of tree biotechnologies into multivarietal forestry // Proc. Third Int. Conf.
IUFRO Unit 2.09.02 on Woody Plant Production Integrating Genetic and Vegetative Propagation Technologies, Vitoria-Gasteiz, Spain.

5. Fourre JL, Berger P, Niquet L, André P (1997) Somatic embryogenesis and somaclonal variation in Norway spruce: morphogenetic, cytogenetic and molecular approaches. Theor Appl Genet 94(2): 159169.

6. Von Aderkas P, Pattanavibool R, Hristoforoglu K, Ma Y (2003) Embryogenesis and genetic stability in long term mega gametophytederived cultures of larch. Plant Cell, Tissue and Organ Culture 74(1): 27-34.

7. Marum L, Rocheta M, Maroco J, Oliveira M, Miguel C, et al. (2009) Analysis of genetic stability at SSR loci during somatic embryogenesis in maritime pine (Pinus pinaster). Plant Cell Rep 28(4): 673-682.

8. Burg K, Helmersson A, Bozhkov P, von Arnold S (2007) Developmental and genetic variation in nuclear microsatellite stability during somatic embryogenesis in pine. J Exp Bot 58(3): 687-698.

9. Mo LM, von Arnold S, Lagererantz U (1989) Morphogenic and genetic stability in long term Embryogenic cultures and somatic embryos of Norway spruce (Picea abies [L.] Karst.). Plant Cell Rep 8: 375-378.

10. Eastman P, Webster FB, Pitel JA, Roberts DR (1991) Evaluation of somaclonal variation during somatic embryogenesis of interior spruce (Picea glauca engelmanii complex) using culture morphology and isozyme analysis. Plant Cell Rep 10(8): 425-430.

11. Tremblay L, Levasseur C, Tremblay FM (1999) Frequency of somaclonal variation in plants of black spruce Picea mariana Pinaceae) and white spruce (P. glauca Pinaceae) derived from somatic embryogenesis and identification of some factors involved in genetic instability. Am J Bot 86(10): 1373-1381.

12. Harvengt L, Trontin JF, Reymond I, Canlet F, Pâques M, et al. (2001) Molecular evidence of true-to-type propagation of a 3-yearold Norway spruce through somatic embryogenesis. Planta 213(5): 828-832.

13. Helmersson A, von Arnold S, Burg K, Bozhkov PV (2004) High stability of nuclear microsatellite loci during the early stages of somatic embryogenesis in Norway spruce. Tree Physiology 24: 1181-1186.

14. Arrillaga I, Guevara MA, Munnoz Bertomeu J, Lazaro-Gimeno D, Saez Laguna E, et al. (2014) Selection of haploid cell lines from mega gametophyte cultures of martime pine as a DNA source for massive sequencing of the species. Plant Cell Tiss Organ Cult 118(1): 147-155.

15. Tretyakova IN, Pak ME, Ivanizkaja AS, Oreskova NV (2016) Peculiarities of Somatic Embryogenesis of Long-Term Proliferation Embryogenic Cell lines of Larix sibirica in vitro. Russian Journal of Plant Physiology 63(6): 800-810.

16. Devey ME, Bell JC, Smith DN, Neale DB, Moran GF, et al. (1996) a genetic linkage map for Pinus radiate based on RFLP, RAPD, and microsatellite markers. Theor Appl Genet 92(6): 673-679.

17. Krutovsky KV, Tretyakova IN, Oreshkova NV, Pak ME, Kvitko OV, et al. (2014) Somaclonal variation of haploid in vitro tissue culture obtained from Siberian larch (Larix sibirica Ledeb.) mega gametophytes for whole genome de novo sequencing. In Vitro Cell Dev Biol Plant 50(5): 655-664.

18. Shmidt VM (1984) Matematicheskie metody v botanike (Mathematical methods in botany) Leningrad: Izd-voLeningr Univ, USA, p.288 


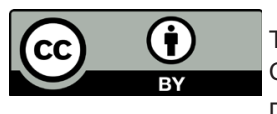

This work is licensed under Creative Commons Attribution 4.0 Licens DIO: 10.19080/IJCSMB.2017.2.555592

\section{Your next submission with Juniper Publishers} will reach you the below assets

- Quality Editorial service

- Swift Peer Review

- Reprints availability

- E-prints Service

- Manuscript Podcast for convenient understanding

- Global attainment for your research

- Manuscript accessibility in different formats

( Pdf, E-pub, Full Text, Audio)

- Unceasing customer service

Track the below URL for one-step submission https://juniperpublishers.com/online-submission.php 